\title{
Analisis Kesalahan Siswa Dalam Menyelesaikan Soal Sistem Persamaan Linear Tiga Variabel Berdasarkan Prosedur Kesalahan Newman
}

\author{
Sherli Pitrah Dewi ${ }^{1}$, Kartini Kartini ${ }^{2}$ \\ ${ }^{1,2}$ Program Studi Pendidikan Matematika, Fakultas Keguruan dan Ilmu Pendidikan, Universitas Riau, \\ Kampus Bina Widya Km 12,5 Simpang Baru, Pekanbaru, Indonesia \\ sherlipitrahdewi80@gmail.com
}

\begin{abstract}
This research is motivated by the number of students who make mistakes in working on the questions, so that it can be a clue to find out how much students understand the material. SPLTV material was chosen for this study because SPLTV has components that must be understood by students so that it can easily determine the mistakes made by students. The purpose of this study was to describe the types of mistakes students make in solving the three-variable linear equation system using Newman's error analysis procedure. This type of research is quadrantic research. The subject of this study was taken using purposive sampling and obtained by grade X MIA 1 students of 25 students. The data collection technique in this study is a written test. Based on the results of data analysis, conclusions were obtained that showed that students made mistakes at the Newman stages, namely: reading errors as much as $4 \%$, misreading as much as $11 \%$, transformation errors as much as $35 \%$, process skills errors as much as $19 \%$, and writing errors / notation as much as $15 \%$. Factors that cause errors, namely: less thorough, unable to read problems, not understanding problems, haste, and not knowing the steps to solve the problem.
\end{abstract}

Keywords: Error Analysis, Newman, Three Variable Linear Equation System.

\begin{abstract}
Abstrak
Penelitian ini dilatarbelakangi oleh banyaknya siswa yang melakukan kesalahan dalam mengerjakan soal, sehingga dapat menjadi petunjuk untuk mengetahui seberapa paham siswa terhadap materi. Materi SPLTV dipilih untuk penelitian ini karena SPLTV memiliki komponen-komponen yang harus dipahami oleh siswa sehingga dapat dengan mudah menentukan kesalahan yang dilakukan oleh siswa. Tujuan penelitian ini adalah untuk mendeskripsikan jenis kesalahan yang dilakukan siswa dalam menyelesaikan soal sistem persamaan linear tiga variabel menggunakan prosedur analisis kesalahan Newman. Jenis penelitian ini adalah penelitian kualitataif. Subjek penelitian ini diambil dengan menggunakan purposive sampling dan diperoleh siswa kelas X MIA 1 yang berjumlah 25 siswa. Teknik pengumpulan data dalam penelitian ini adalah tes tertulis. Berdasarkan hasil analisis data, diperoleh kesimpulan yang menunjukkan bahwa siswa melakukan kesalahan pada tahapan-tahapan Newman, yaitu: kesalahan membaca sebanyak 4\%, kesalahan memahami sebanyak 11\%, kesalahan transformasi sebanyak 35\%, kesalahan keterampilan proses sebanyak 19\%, dan kesalahan penulisan/ notasi sebanyak $15 \%$. Faktor-faktor yang menyebabkan terjadinya kesalahan, yaitu: kurang teliti, tidak mampu membaca soal, tidak memahami masalah, dan tidak mampu melakukan prosedur atau langkah-langkah yang akan digunakan untuk menyelesaikan soal.
\end{abstract}

Kata kunci: Analisis Kesalahan, Newman, Sistem Persamaan Linear Tiga Variabel.

Copyright (c) 2021 Sherli Pitrah Dewi, Kartini

$\square$ Corresponding author: Kartini Kartini

Email Address: kartini@lecturer.unri.ac.id

Received 02 Februari 2021, Accepted 16 Maret 2021, Published 20 Maret 2021

\section{PENDAHULUAN}

Matematika merupakan salah satu ilmu dasar yang diberikan sejak pendidikan dasar sampai sekolah menengah, dimana matematika memiliki fungsi yang sangat penting dalam kehidupan seharihari (Khatimah et al., 2017). Menurut (Susanto, 2013) yang mengatakan bahwa matematika merupakan salah satu disiplin ilmu yang dapat meningkatkan kemampuan berpikir dan berargumentasi, memberikan kontribusi dalam penyelesaian masalah sehari-hari dan dalam dunia kerja, serta dapat menjadi penyokong dalam pengembangan ilmu pengetahuan dan teknologi.

Melalui pembelajaran matematika siswa diharapkan dapat mengembangkan kemampuan berpikir 
kritis, logis, sistematis, cermat, efektif, dan efisien dalam memecahkan masalah. Tujuan pembelajaran matematika dapat dikatakan tercapai apabila salah satunya dapat dinilai dari keberhasilan siswa dalam memahami matematika dan memanfaatkan pemahaman ini untuk menyelesaikan persoalan-persoalan matematika maupun ilmu-ilmu lainnya. Akan tetapi, dalam kenyataannya matematika masih menjadi suatu mata pelajaran yang didalam bayang-bayang siswa merupakan mata pelajaran yang berat dan sulit untuk dimengerti. Untuk mempelajari matematika setidaknya siswa sudah memiliki kemampuan untuk memahami konsep terlebih dahulu, karena dengan pemahaman konsep ini siswa akan mampu untuk mengkonstruksi makna yang dimaksud (Fajar et al., 2018).

Pokok bahasan Sistem persamaan linear tiga variabel (SPLTV) merupakan salah satu materi dalam mata pelajaran matematika. Materi ini diajarkan pada jenjang SMA kelas $X$, materi ini juga dinilai memiliki tingkatan yang lumayan sulit. Karena rata-rata materi ini mengambil contoh pada kehidupan sehari-hari, dan penyajian soal dalam materi ini banyak yang berbentuk soal cerita. Penyajian soal yang berbentuk cerita merupakan suatu usaha untuk memberikan stimulus kepada siswa, agar siswa dapat membayangkan konsep materi ini dalam kehidupan sahari-hari. Penerapan soal cerita inilah yang kemudian membuat materi sistem persamaan linear tiga variabel menjadi materi yang lumayan sulit.

(Suyitno \& Suyitno, 2015) menyatakan bahwa analisis Newman bisa digunakan untuk menentukan jenis kesalahan siswa dalam melakukan masalah matematika secara tertulis dengan mengetahui jenis kesalahan siswa dalam melakukan masalah matematika, maka guru dapat memberikan solusi belajar sehingga siswa dapat menjadi benar dan akurat dalam mengkomunikasikan ide-ide melalui menulis solusi. Beberapa penelitian menganalisis kesalahan siswa didalam menyelesaikan soal cerita menggunakan analisis Newman misalnya penelitian (Amalia et al., 2018) dalam pokok bahasan persamaan linear, (Zulkarnaen, 2017) dan (Rahmania \& Rahmawati, 2016) dalam pokok bahasan sistem persamaan linear satu variabel dengan jenis kesalahan yang diteliti adalah reading, comprehention, transformation, process skill, dan endcoding.

Dengan menganalisis kesalahan siswa, penulis berharap hasil analisis ini dapat membantu siswa untuk dapat mengetahui jenis kesalahan dan faktor penyebab terjadinya kesalahan siswa pada materi sistem persamaa linear tiga variabel (SPLTV) berdasarkan tahapan Newman. Oleh karena itu, penelitian ini difokuskan pada analisis kesalahan siswa menggunakan teori Newman dalam menyelesaikan soal matematika pada materi sistem persamaan linear tiga variabel (SPLTV).

\section{METODE}

Jenis penelitian ini adalah penelitian kualitatif. (Moleong, 2017) menjelaskan bahwa penelitian kualitatif ini bermaksud untuk memahami jenis kesalahan yang dilakukan oleh subjek penelitian dalam menyelesaikan soal matematika. Adapun metode yang digunakan dalam penelitian ini adalah metode deskriptif, yaitu untuk mengetahui gambaran tentang kesalahan siswa dalam menyelesaikan soal pada materi sistem persamaa linear tiga variabel (SPLTV).

Subjek penelitian adalah siswa SMA kelas X MIA 1 SMAN 1 Bangkinang Kota sebanyak 25 siswa. 
Teknik pengumpulan data yang digunakan dalam penelitian ini berupa tes tertulis. Dalam hal ini tes bertujuan untuk mengetahui letak kesalahan siswa berdasarkan tahapan analisis Newman, berbentuk soal tes uraian sebanyak 3 butir soal yang berisikan soal-soal persamaan linear tiga variabel. Pengujian validitas instrumen menggunakan validitas isi. Validitas isi merupakan pengujian validitas dengan menggunakan kisi-kisi soal yang didalamnya terdapat indikator sebagai tolak ukur dan nomor butir pertanyaan-pertanyaan yang telah dijabarkan oleh indikator tersebut dan untuk menguji validitas lebih lanjut, maka dikonsultasikan kepada ahli (Sugiyono, 2012). Berdasarkan perhitungan validitas, reliabilitas, tingkat kesukaran, dan daya beda, berikut adalah rekapitulasi dari hasil perhitungan uji validitas, reliabilitas, daya pembeda, dan tingkat kesukaran dari uji coba soal dapat dilihat pada tabel 1:

Tabel 1. Rekapitulasi Hasil Uji Coba Soal

\begin{tabular}{|c|c|c|c|c|c|}
\hline $\begin{array}{c}\text { No. Butir } \\
\text { Soal }\end{array}$ & Validitas & Reliabilitas & $\begin{array}{c}\text { Daya } \\
\text { Beda }\end{array}$ & $\begin{array}{c}\text { Tingkat } \\
\text { Kesukaran }\end{array}$ & Keterangan \\
\hline 1 & Valid & \multirow{3}{*}{ Tinggi } & Baik & Sedang & Digunakan \\
\hline 2 & Valid & Cukup & Mudah & Digunakan \\
\cline { 1 - 5 } \cline { 4 - 6 } & Valid & & Cukup & Sedang & Digunakan \\
\hline 3 & & &
\end{tabular}

Untuk mengetahui klasifikasi kesalahan yang dilakukan oleh siswa, data diperoleh dianalisis dengan menggunakan teori Newman dengan indikator-indikator sebagai berikut:

Tabel 2. Indikator Kesalahan Siswa Berdasarkan Prosedur Kesalahan Newman

\begin{tabular}{|c|c|c|}
\hline No & $\begin{array}{c}\text { Tahapan dalam Analisis } \\
\text { Kesalahan Newman }\end{array}$ & Indikator Kesalahan \\
\hline 1 & Membaca (Reading) & $\begin{array}{l}\text { - Kurang teliti } \\
\text { - Siswa tidak mampu membaca atau mengenal simbol- } \\
\text { simbol dalam soal } \\
\text { - Siswa tidak mampu memaknai arti setiap kata, istilah atau } \\
\text { simbol dalam soal }\end{array}$ \\
\hline 2 & $\begin{array}{l}\text { Memahami } \\
\text { (Comprehention) }\end{array}$ & $\begin{array}{l}\text { - Siswa tidak mampu memahami apa saja yang diketahui } \\
\text { dengan lengkap } \\
\text { - Siswa tidak mampu memahami apa saja yang ditanyakan } \\
\text { dengan lengkap }\end{array}$ \\
\hline 3 & $\begin{array}{l}\text { Transformasi } \\
\text { (Transformation) }\end{array}$ & $\begin{array}{l}\text { - Siswa tidak mampu membuat model } \\
\text { matematis dari informasi yang disajikan } \\
\text { - Siswa mengubah informasi yang terdapat pada soal ke } \\
\text { dalam model matematika tetapi tidak tepat }\end{array}$ \\
\hline 4 & $\begin{array}{l}\text { Keterampilan Proses } \\
\text { (Process Skill) }\end{array}$ & $\begin{array}{l}\text { - Kesalahan dalam komputasi } \\
\text { - Siswa tidak mampu melakukan prosedur atau langkah- } \\
\text { langkah yang akan digunakan untuk menyelesaikan soal } \\
\text { - Ceroboh dalam proses perhitungan }\end{array}$ \\
\hline 5 & $\begin{array}{l}\text { Penulisan/ Notasi } \\
\text { (Encoding) }\end{array}$ & $\begin{array}{l}\text { - Menuliskan notasi (tanda negatif, simbol, tanda sama } \\
\text { dengan, dll) secara tidak tepat } \\
\text { - Tidak menuliskan variabel/ satuan } \\
\text { - Salah penggunaan satuan } \\
\text { - Siswa tidak menuliskan kesimpulan }\end{array}$ \\
\hline
\end{tabular}

Sumber: dimodifikasi dari Savitri dan Yuliani (2020) 
Teknik analisis Newman digunakan untuk menganalisis letak kesalahan siswa dalam menyelesaikan soal, yang terdiri dari kesalahan: reading, comprehention, transformation, process skill, dan encoding. Hasil jawaban tes dikoreksi berdasarkan kunci jawaban. Peneliti memberikan sedikit pengarahan tentang proses pengerjaannya. Saat tes akan diberikan, siswa diberi kebebasan untuk mengerjakan sesuai dengan kemampuan masing-masing.

Dalam analisis data, peneliti melakukan analisis data tes dari seluruh siswa yang melakukan tes tertulis, dianalisis oleh peneliti untuk mengetahui kesalahan siswa. Kemudian jawaban siswa yang dianalisis adalah jawaban yang salah dan yang tidak menjawab. Siswa yang tidak menjawab secara langsung telah melakukan kesalahan maksimum yaitu melakukan 5 indikator kesalahan berdasarkan tahapan analisis Newman.

\section{HASIL DAN DISKUSI}

Peneliti melakukan analisis data hasil jawaban tes siswa, selanjutnya dilakukan analisis untuk mendeskripsikan jenis-jenis kesalahan siswa. Instrumen penelitian ini menggunakan soal uraian dari sistem persamaan linear tiga variabel (SPLTV). Teknik analisis Newman digunakan untuk menganalisis letak kesalahan siswa dalam menyelesaikan soal, yang terdiri dari kesalahan: reading, comprehention, transformation, process skill dan encoding. Kesalahan yang dilakukan oleh siswa dapat dilihat pada tabel 3:

Tabel 3. Jumlah Siswa yang Melakukan Kesalahan berdasarkan Teori Newman

\begin{tabular}{|c|c|c|c|c|c|c|}
\hline No. Soal & $\begin{array}{c}\text { Reading } \\
\text { error }\end{array}$ & $\begin{array}{c}\text { Comprehention } \\
\text { error }\end{array}$ & $\begin{array}{c}\text { Transformation } \\
\text { error }\end{array}$ & $\begin{array}{c}\text { Process } \\
\text { skill } \\
\text { error }\end{array}$ & $\begin{array}{c}\text { Encoding } \\
\text { error }\end{array}$ & Jumlah \\
\hline 1 & 0 & 2 & 9 & 4 & 4 & 19 \\
\hline 2 & 0 & 2 & 10 & 4 & 2 & 18 \\
\hline 3 & 3 & 4 & 7 & 6 & 5 & 25 \\
\hline Jumlah & 3 & 8 & 26 & 14 & 11 & \\
\hline Persentase & $4 \%$ & $11 \%$ & $35 \%$ & $19 \%$ & $15 \%$ & \\
\hline Rata-rata & \multicolumn{7}{l}{} \\
\hline
\end{tabular}

Untuk menganalisis kesalahan yang dilakukan siswa dalam menyelesaikan soal, dilakukan analisis yang lebih mendalam terhadap kelompok-kelompok siswa pada masing-masing soal pada jenisjenis kesalahan yang dilakukan siswa berdasarkan tahapan kesalahan Newman. Identifikasi kesalahan siswa yang di peroleh berdasarkan kesalahan siswa mengerjakan tes, sebagai berikut:

\section{Kesalahan Membaca (Reading Error)}

Berdasarkan data hasil jawaban siswa, peneliti akan menganalisis kesalahan yang dilakukan siswa pada setiap butir soal yang telah dikerjakan. Berikut adalah persentase kesalahan pada reading error untuk setiap soal: 
Tabel 4. Kesalahan Membaca (Reading Error)

\begin{tabular}{|c|c|c|}
\hline No. Soal & Reading error & Persentase \\
\hline 1 & 0 & $0 \%$ \\
\hline 2 & 0 & $0 \%$ \\
\hline 3 & 3 & $12 \%$ \\
\hline \multicolumn{2}{|c|}{ Rata-rata } & $4 \%$ \\
\hline
\end{tabular}

Dipilih subjek siswa S-2 sebagai contoh dari kesalahan yang dilakukan siswa. Kesalahan pada butir soal nomor 3 dilakukan oleh beberapa siswa. Berdasarkan jawaban siswa pada soal nomor 3 terdapat siswa yang melakukan kesalahan yaitu kesalahan dalam membaca informasi utama yang terdapat dalam soal. Berikut hasil jawaban siswa.

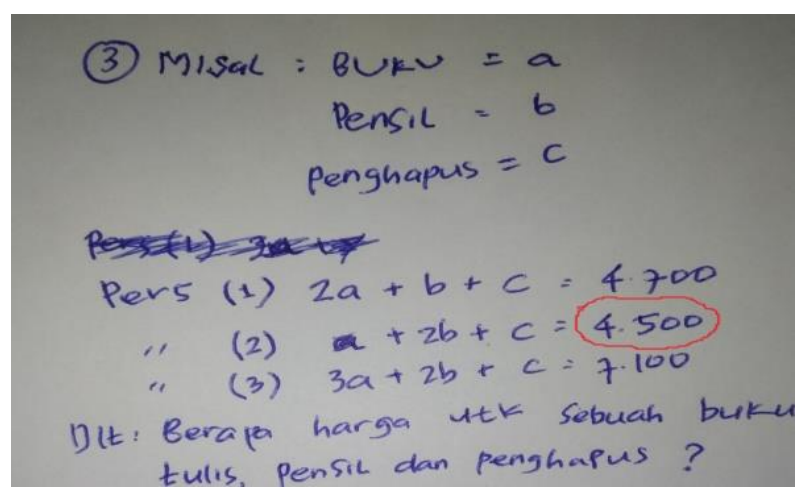

Gambar 1. Kesalahan siswa dalam membaca

Dari jawaban siswa pada Gambar 1 di atas menunjukkan bahwa siswa S-2 kurang teliti dalam membaca informasi yang tertulis pada soal. Hal tersebut ditunjukkan dengan jawaban siswa S-2 terlihat bahwa siswa salah membuat model matematikanya, karena informasi dalam soal adalah 1 buku tulis, 2 pensil dan 1 penghapus seharga 4300 rupiah, tetapi siswa tersebut malah menuliskannya $a+2 b+c=$ 4500. Oleh karena itu, jawaban tersebut dinyatakan bahwa siswa S-2 salah dalam membaca informasi pada soal. Hal ini sejalan dengan penelitian yang dilakukan oleh (Ma'rifah et al., 2020) yang menyimpulkan bahwa siswa melakukan kesalahan pada tahap membaca informasi yang tertulis dalam soal disebabkan oleh siswa kurang teliti dan terburu-buru dalam membaca soal sehingga mengakibatkan siswa kesulitan dalam memahami masalah yang terdapat dalam soal.

\section{Kesalahan Memahami (Comprehention Error)}

Berdasarkan data hasil jawaban siswa, peneliti akan menganalisis kesalahan yang dilakukan siswa pada setiap butir soal yang telah dikerjakan. Berikut adalah persentase kesalahan pada comprehention error untuk setiap soal: 
Tabel 4.2 Kesalahan Memahami (Comprehention Error)

\begin{tabular}{|c|c|c|}
\hline No. Soal & Comprehention Error & Persentase \\
\hline 1 & 2 & $8 \%$ \\
\hline 2 & 2 & $8 \%$ \\
\hline 3 & 4 & $16 \%$ \\
\hline \multicolumn{2}{|c|}{ Rata-rata } & $11 \%$ \\
\hline
\end{tabular}

Dipilih subjek siswa S-17 sebagai contoh dari kesalahan yang dilakukan siswa. Kesalahan pada butir soal nomor 3 dilakukan oleh beberapa siswa. Berdasarkan jawaban siswa pada soal nomor 3 terdapat siswa melakukan kesalahan yaitu kesalahan dalam memahami masalah yang terdapat dalam soal. Berikut hasil jawaban siswa.

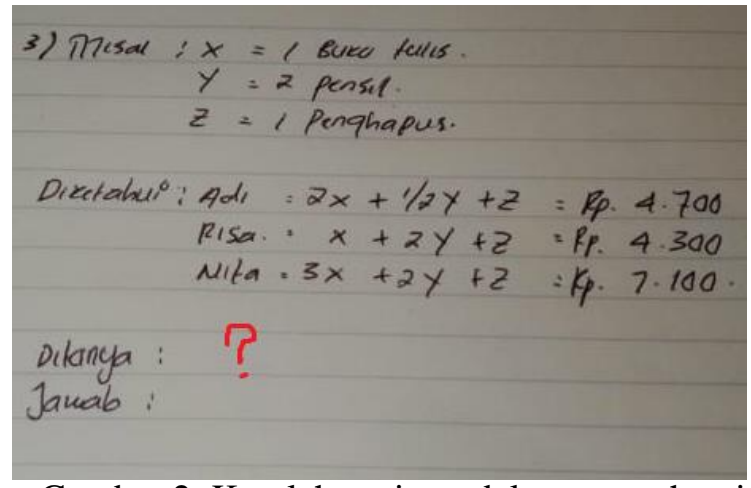

Gambar 2. Kesalahan siswa dalam memahami

Dari jawaban siswa pada Gambar 2 di atas menunjukkan bahwa siswa S-17 kesulitan dalam memahami soal. Hal tersebut ditunjukkan dengan jawaban siswa S-17 yang menuliskan seadanya hanya membuat apa yang diketahui oleh soal, jawabannya tanpa ada perhitungan sama sekali. Siswa S-17 terlihat belum memahami maksud soal, karena siswa sama sekali tidak menuliskan apa yang ditanya dari soal sehingga siswa akan sulit untuk melanjutkan dalam menjawab soal. Oleh karena itu, jawaban siswa tersebut dinyatakan bahwa siswa kesulitan dalam memahami masalah pada soal. Hal tersebut sejalan dengan hasil penelitian yang dilakukan oleh (Darmawan et al., 2018) yang menyatakan bahwa salah satu penyebab terjadinya kesalahan memahami (comprehention error) karena siswa tidak bisa menyebutkan apa yang diketahui dengan lengkap dari soal.

\section{Kesalahan Transformasi (Transformation Error)}

Berdasarkan data hasil jawaban siswa, peneliti akan menganalisis kesalahan yang dilakukan siswa pada setiap butir soal yang telah dikerjakan. Berikut adalah persentase kesalahan pada transformation error untuk setiap soal:

Tabel 5. Kesalahan Transformasi (Transformation Error)

\begin{tabular}{|c|c|c|}
\hline No. Soal & Transformation error & Persentase \\
\hline 1 & 9 & $36 \%$ \\
\hline 2 & 10 & $40 \%$ \\
\hline 3 & 7 & $28 \%$ \\
\hline \multicolumn{2}{|c|}{ Rata-rata } & $35 \%$ \\
\hline
\end{tabular}


Dipilih subjek siswa S-6 sebagai contoh dari kesalahan yang dilakukan siswa. Kesalahan pada butir soal nomor 3 dilakukan oleh beberapa siswa. Berdasarkan jawaban siswa pada soal nomor 3 terdapat siswa melakukan kesalahan yaitu kesalahan dalam mentransformasikan soal kedalam bentuk matematis yang terdapat dalam soal. Berikut hasil jawaban siswa.

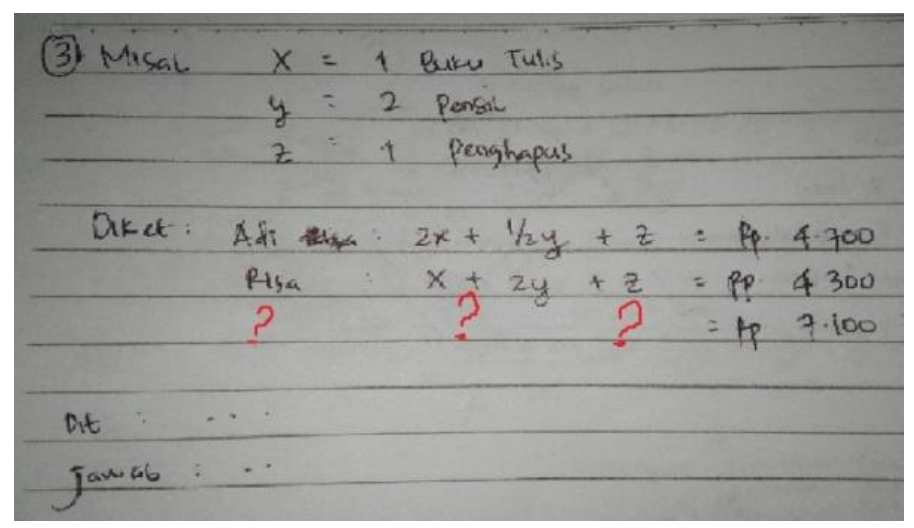

Gambar 3. Kesalahan siswa dalam transformasi

Dari jawaban siswa pada Gambar 3 di atas menunjukkan bahwa siswa S-6 belum mampu dalam mentransformasikan soal kedalam bentuk matematis. Kesalahan siswa S-6 adalah tidak mengubah informasi pada soal kedalam model matematisnya pada pernyataan yang ketiga. Oleh karena itu, pada jawaban tersebut dinyatakan bahwa siswa S-6 tidak mampu dalam mentransformasikan soal kedalam bentuk matematis. Hal ini sejalan dengan hasil penelitian yang dilakukan oleh (Singh et al., 2010) menyatakan bahwa kesalahan transformasi terjadi ketika siswa paham akan apa yang diinginkan dari pertanyaan tetapi tidak bisa mengidentifikasikan operasi maupun barisan operasi yang dibutuhkan untuk menyelesaikan soal. Kemungkinan lain penyebab terjadinya kesalahan transformasi karena siswa kurang teliti dalam menentukan informasi mengenai apa yang diketahui dan ditanyakan dalam soal (Manibuy \& Mardiyana, 2014) serta tidak mampu menerjemahkan kalimat soal ke dalam kalimat (model) matematika (Wijaya \& Masriyah, 2013).

\section{Kesalahan Keterampilan Proses (Process Skill Error)}

Berdasarkan data hasil jawaban siswa, peneliti akan menganalisis kesalahan yang dilakukan siswa pada setiap butir soal yang telah dikerjakan. Berikut adalah persentase kesalahan pada process skill error untuk setiap soal:

Tabel 6. Kesalahan Keterampilan Proses (Process Skill Error)

\begin{tabular}{|c|c|c|}
\hline No. Soal & Process Skill Error & Persentase \\
\hline 1 & 4 & $16 \%$ \\
\hline 2 & 4 & $16 \%$ \\
\hline 3 & 6 & $24 \%$ \\
\hline \multicolumn{2}{|c|}{ Rata-rata } & $19 \%$ \\
\hline
\end{tabular}

Dipilih subjek siswa S-14 sebagai contoh dari kesalahan yang dilakukan siswa. Kesalahan pada butir soal nomor 1 dilakukan oleh beberapa siswa. Berdasarkan jawaban siswa pada butir soal nomor 1 
terdapat siswa melakukan kesalahan yaitu kesalahan siswa dalam keterampilan proses pada saat mengerjakan soal. Berikut hasil jawaban siswa.

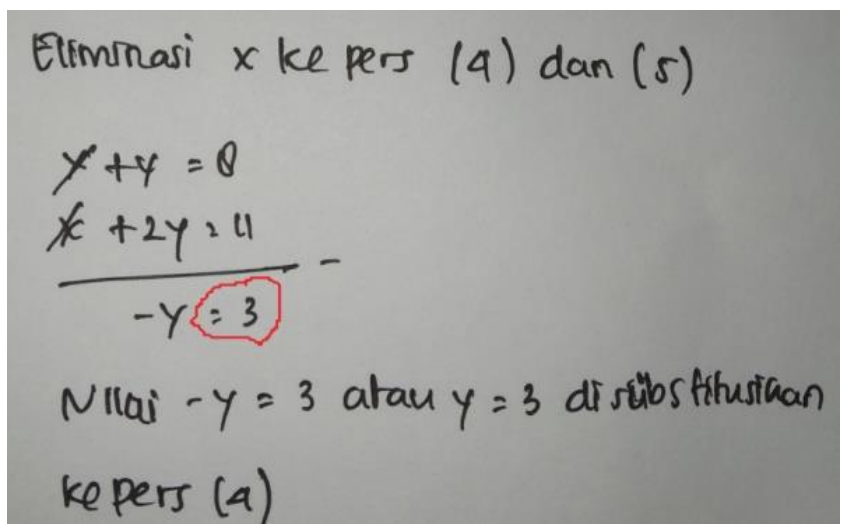

Gambar 4. Kesalahan Siswa Dalam Keterampilan Proses

Dari jawaban siswa pada Gambar 4 di atas menunjukkan bahwa siswa S-14 lemah dalam keterampilan proses karena siswa salah dalam menuliskan hasil yang didapati dari persamaan yang telah dituliskan sebelumnya. Kesalahan siswa S-14 adalah tidak mampu melakukan proses operasi pengurangan dengan benar. Oleh karena itu, pada jawaban tersebut dinyatakan bahwa siswa S-14 lemah dalam keterampilan proses. Hal ini sejalan dengan hasil penelitian yang dilakukan oleh (Hidayanto et al., 2017) yang mengatakan kesalahan process skills error ini dikarenakan siswa melakukan miskonsepsi, kurangnya background pengetahuan dan penalaran, serta kesalahan pada perhitungan operasi dasar.

\section{Kesalahan Penulisan/ Notasi (Encoding Error)}

Berdasarkan data hasil jawaban siswa, peneliti akan menganalisis kesalahan yang dilakukan siswa pada setiap butir soal yang telah dikerjakan. Berikut adalah persentase kesalahan pada encoding error untuk setiap soal:

Tabel 7. Kesalahan Penulisan/ Notasi (Encoding Error)

\begin{tabular}{|c|c|c|}
\hline No. Soal & Encoding error & Persentase \\
\hline 1 & 4 & $16 \%$ \\
\hline 2 & 2 & $8 \%$ \\
\hline 3 & 5 & $20 \%$ \\
\hline \multicolumn{2}{|c|}{ Rata-rata } & $15 \%$ \\
\hline
\end{tabular}

Dipilih subjek siswa S-18 sebagai contoh dari kesalahan yang dilakukan siswa. Kesalahan pada butir soal nomor 2 dilakukan oleh beberapa siswa. Berdasarkan jawaban siswa pada butir soal nomor 2 terdapat siswa melakukan kesalahan yaitu kesalahan siswa dalam menyimpulkan dari jawaban yang siswa peroleh. Berikut hasil jawaban siswa. 


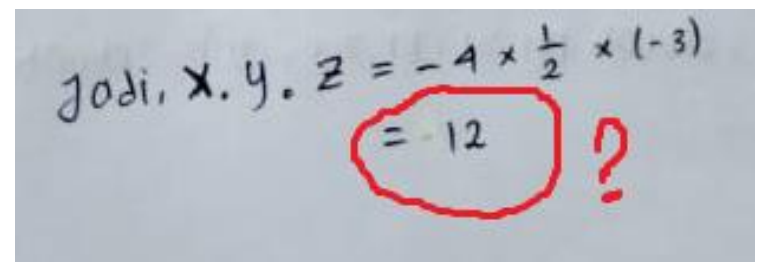

Gambar 5. Kesalahan siswa dalam penulisan/ notasi

Dari jawaban siswa pada Gambar 5 di atas menunjukkan bahwa siswa S-18 salah dalam menyimpulkan hasil akhir. Hal tersebut ditunjukkan oleh jawaban siswa S-18 yang dalam menuliskan jawaban akhir. Jawaban tersebut salah dalam menyimpulkan hasil akhir. Oleh karena itu, siswa S-18 masih belum mampu dalam menyimpulkan hasil akhir yang dimaksud oleh soal tersebut. Sejalan dengan hasil penelitian yang dilakukan oleh (Seto Satoto et al., 2012), (Abdullah et al., 2015), serta (Amalia et al., 2018) yang menyatakan siswa melakukan kesalahan jawaban akhir, disebabkan siswa tidak menuliskan hasil akhir sesuai prosedur atau langkah-langkah yang digunakan.

\section{KESIMPULAN}

Berdasarkan hasil jawaban siswa dapat disimpulkan bahwa, kesalahan siswa dalam menyelesaikan soal SPLTV adalah kesalahan reading (membaca) sebanyak 4\%. Kesalahan comprehension (memahami soal) sebanyak 11\%. Kesalahan transformation (transformasi) sebanyak $35 \%$. Kesalahan process skill (kesalahan keterampilan proses) sebanyak 19\%. Kesalahan encoding (menggunakan notasi) sebanyak 15\%. Mayoritas siswa melakukan kesalahan transformation dan process skill. Pada kesalahan transformation yang disebabkan siswa tidak mampu menuliskan informasi pada soal kedalam model matematisnya. Kesalahan yang dilakukan siswa yaitu tidak mengubah informasi pada soal kedalam model matematikanya dan banyak siswa yang sudah mengubah informasi pada soal, tetapi tidak menuliskan keterangan secara lengkap. Sedangkan, mayoritas siswa melakukan kesalahan process skill yang disebabkan kesalahan dalam komputasi dan ceroboh dalam proses perhitungan, yang dikarenakan kelemahan siswa dalam memanipulasi matematika.

Solusi untuk dapat meminimalkan kesalahan siswa dalam menyelesaikan soal SPLTV adalah siswa perlu mendapat penguatan mengenai pengetahuan tentang simbol-simbol atau istilah matematika, siswa perlu diberikan penjelasan menggunakan alat peraga yang konkret atau nyata, siswa perlu dilatih untuk memahami masalah dalam soal secara keseluruhan, siswa perlu dibiasakan untuk menyelesaikan soal cerita secara matematis dan jelas, dan guru sebaiknya mengingatkan siswa untuk mengecek kembali lembar pekerjaannya sebelum dikumpulkan.

\section{UCAPAN TERIMA KASIH}

Ucapan terimakasih disampaikan kepada semua pihak yang telah ikut berkontribusi dalam penelitian ini sehingga penelitian terlaksana dengan baik dan hasilnya bisa dituangkan dalam tulisan ini dan diinformasikan kepada pembaca. 


\section{REFERENSI}

Abdullah, A. H., Abidin, N. L. Z., \& Ali, M. (2015). Analysis of Students' Errors in Solving Higher Order Thinking Skills (HOTS) Problems for the Topic of Fraction. Prosiding Asian Social Science, 11(21), 133

Amalia, R., Aufin, M., \& Khusniah, R. (2018). Analisis Kesalahan dalam Menyelesaikan Soal Cerita pada Pokok Bahasan Persamaan Linier Berdasarkan Newman Kelas X-Mia di SMA Bayt AlHikmah Kota Pasuruan. Prosiding Seminar Nasional Matematika dan Pendidikan Matematika (SNMPM) (Vol. 2, No. 1, pp. 346-359).

Darmawan, I., Kharismawati, A., Hendriana, H., \& Purwasih, R. (2018). Analisis Kesalahan Siswa SMP Berdasarkan Newman dalam Menyelesaikan Soal Kemampuan Berpikir Kritis Matematis pada Materi Bangun Ruang Sisi Datar. JURING (Journal for Research in Mathematics Learning), 1(1), 71-78.

Fajar, A. P., Kodirun, K., Suhar, S., \& Arapu, L. (2018). Analisis Kemampuan Pemahaman Konsep Matematis Siswa Kelas VIII SMP Negeri 17 Kendari. Jurnal Pendidikan Matematika, 9(2), 229239.

Hidayanto,T., Subanji, S., \& Hidayanto, E. (2017) . Deskripsi Kesalahan Struktur Berpikir Siswa SMP Dalam Menyelesaikan Masalah Geometri Serta Defragmentingnya: Suatu Studi Kasus. Jurnal Kajian Pembelajaran Matematika, 1(1), 72-81.

Khatimah, K.., Sa'dijah, C., \& Susanto, H. (2017). Pemberian Scaffolding Untuk Mengatasi Hambatan Berpikir Siswa Dalam Memecahkan Masalah Aljabar. Jurnal Kajian Pembelajaran Matematika, l(1), 36-45.

Manibuy, R., Mardiyana, M., \& Saputro. (2014). Analisis Kesalahan Siswa dalam Menyelesaikan Soal Persamaan Kuadrat Berdasarkan Taksonomi Solo pada Kelas X SMA Negeri 1 Plus di Kabupaten Nabire Papua. Jurnal Pembelajaran Matematika, 2(9), 933-945.

Ma'rifah, C., Sa'dijah, C., Subanji, S., \& Nusantara, T. (2020). Profil Kemampuan Komunikasi Matematis Peserta Didik Dalam Pemecahan Masalah Soal Cerita. Edu Sains: Jurnal Pendidikan Sains dan Matematika, 8(2), 43-56.

Moleong, L. J. (2017). Metode Penelitian Kualitatif. Bandung: PT. Remaja Rosdakarya Offset.

Morales, Z. A. (2014). Analysis of Students' Misconceptions and Error Patterns in Mathematics: The Case of Fractions. Fraction Error Patterns, 1-10.

Rahmania, L., \& Rahmawati, A. (2016). Analisis Kesalahan Siswa Dalam Menyelesaikan Soal Cerita Persamaan Linier Satu Variabel. JMPM: Jurnal Matematika Dan Pendidikan Matematika, 1(2), 165-174.

Satoto, S., Sutarto, H., \& Pujiastuti, E. (2012). Analisis Kesalahan Hasil Belajar Siswa dalam Menyelesaikan Soal dengan Prosedur Newman. Unnes Journal of Mathematics Education, 1(2), $1-7$.

Savitri, D. A., \& Yuliani, A. (2020). Analisis Kesalahan Siswa dalam Menyelesaikan Permasalahan Trigonometri Ditinjau Dari Gender Berdasarkan Newman. JPMI (Jurnal Pembelajaran Matematika Inivatif), 3(5), 463-474.

Singh, P., Rahman, A. A., \& Hoon, T. S. (2010). The Newman Procedure for Analyzing Primary Four Pupils Errors on Written Mathematical Tasks: A Malaysian Perspective. Procedia-Social and Behavioral Sciences 8, 264-271. 
Sugiyono. (2012). Metode Penelitian Kuantitatif, Kualitatif, dan R\&D. Bandung: Alfabeta.

Susanto, A. (2013). Teori Belajar dan Pembelajaran di Sekolah Dasar. Jakarta: Kencana Prenadamedia Grup.

Suyitno, A., \& Suyitno, H. (2015). Learning Therapy for Students in Mathematics Communication Correctly Based-on Application of Newman Procedure (a Case of Indonesian Student). International Journal of Education and Research, 3(1), 529-538.

Wijaya, A. A., \& Masriyah. (2013). Analisis Kesalahan Siswa dalam Menyelesaikan Soal Cerita Materi Sistem Persamaan Linear Dua Variabel. MATHEdunesa, 2(1), 1-7.

Zulkarnaen, R. (2017). Kesalahan Siswa Dalam Menyelesaikan Soal Penalaran Proposional. Seminar Matematika Dan Pendidikan Matematika. UNY, (M-8), (pp. 49-54). 